\title{
MODEL PEMBELAJARAN PROBLEM BASED LEARNING (PBL) UNTUK MENINGKATKAN KEMAMPUAN PEMECAHAN MASALAH MATEMATIS SISWA SMP
}

\section{PROBLEM BASED LEARNING (PBL) LEARNING MODEL TO IMPROVE MATHEMATICAL SOLUTION ABILITY OF SMP STUDENTS}

\author{
Yuliani $^{\mathrm{a}}$,Destiniar $^{\mathrm{b}}$, Jayanti $^{\mathrm{c}}$ \\ aUniversitas PGRI Palembang \\ Jl. A. Yani. Lrg. GotongRoyong 9/10 Ulu Palembang, yuli40575@gmail.com \\ ${ }^{b}$ Universitas PGRI Palembang \\ Jl. A. Yani. Lrg. GotongRoyong 9/10 Ulu Palembang, destiniarpgri@ yahoo.co.id \\ ${ }^{c}$ Universitas PGRI Palembang \\ Jl. A. Yani. Lrg. GotongRoyong 9/10 Ulu Palembang, jayanti2hr@gmail.com
}

\begin{abstract}
ABSTRAK
Tujuan penelitian ini adalah untuk mengetahui Bagaimana peningkatan kemampuan pemecahan masalah matematis siswa setelah diterapkannya Model Pembelajaran Problem Based Learning (PBL) di SMP Negeri 12 Palembang. Penelitian ini merupakan penelitian deskriptif dengan rancangan Pretest and Posttest Group. subjek dalam penelitian ini adalah siswa kelas VII.2. Teknik pengumpulan data dalam penelitian ini menggunakan tes dimana teknik analisis datanya menggunakan gain ternormalisasi. Berdasarkan hasil analisis uji $\mathrm{N}$-Gain data tes awal (pretest) dan tes akhir (postest) diperoleh indeks gain 0,62 yang interpretasinya sedang dengan nilai rata-rata Pretest yaitu 55,64 dan nilai rata-rata Posttest yaitu 83,32. Maka dapat disimpulkan peningkatan kemampuan pemecahan masalah matematis siswa setelah diterapkan model pembelajaran Problem Based Learning (PBL) di SMP Negeri 12 Palembang di katagorikan sedang.
\end{abstract}

Kata Kunci : Problem Based Learning (PBL), pemecahan masalah matematis.

\section{ABSTRACT}

The purpose of this study was to find out how to improve students' mathematical problem solving abilities after the implementation of the Problem Based Learning (PBL) Learning Model at 12 State Junior High School Palembang. This research is a descriptive study with a Pretest and Posttest Group design. The subjects in this study were students of class VII.2. Data collection techniques in this study used a test where the data analysis technique used normalized gain. Based on the results of the analysis of the $N$-Gain test the initial test data (pretest) and the final test (posttest) obtained a gain index of 0.62 with moderate interpretation with a pretest average value of 55.64 and an average posttest score of 83.32. Then it can be concluded increasing the students' mathematical problem solving ability after applying the Problem Based Learning (PBL) learning model in 12 State Junior High School Palembang in the medium category.

Keywords: Problem Based Learning (PBL), mathematical problem solving 


\section{Pendahuluan}

Matematika sebagai salah satu pengetahuan mendasar dinilai memegang peranan yang sangat penting dalam membentuk siswa yang berkualitas dan cerdas, oleh karena itu matematika merupakan salah satu mata pelajaran yang diajarkan pada semua jenjang pendidikan, mulai dari tingkat dasar, tingkat menengah, bahkan sampai tingkat perguruan tinggi. Salah satu kemampuan yang harus dikembangkan untuk mencapai tujuan pembelajaran matematika adalah kemampuan pemecahan masalah.

Kemampuan Pemecahan Masalah Matematis siswa akan matematika cenderung relatif kecil, hal ini dibuktikan ketika peneliti melakukan pengajaran selama Praktek Pengabdian Lapangan (PPL) SMP Negeri 12 Palembang (2018), guru masih menggunakan pembelajaran konvensional yaitu guru hanya mentransfer ilmunya langsung kepada siswa, dengan kata lain guru yang aktif sedangkan siswa pasif dalam belajar. Guru hanya memberikan penjelasan materi, contoh dan latihan soal saja dan siswa hanya menerima pengetahuan yang diberikan oleh guru tanpa berusaha apa yang harus dipelajari dari materi tersebut. Guru kurang memberikan kesempatan pada siswa untuk meningkatkan kemampuan siswa sehingga kemampuan pemecahan masalah siswa kurang berkembang dan terlihat sulit untuk mengerjakan soal dan memecahkan masalah yang diberikan.

Berdasarkan hal itu, untuk meningkatakan kualitas pembelajaran pemilihan model pembelajaran yang tepat juga sangat mempengaruhi prestasi belajar siswa. Sebagai contoh, jika model pembelajaran itu membosankan dan bersifat satu arah, maka prestasi belajar siswa tidak akan maksimal, dan sebaliknya model pembelajaran yang menyenangkan dan bersifat interaktif boleh jadi akan meningkatakan prestasi belajar siswa. Salah satu upaya dalam meningkatkan kemampuan pemecahan masalah ialah dengan melakukan inovasi pada model pembelajaran yang digunakan. Salah satu model yang dapat digunakan oleh guru untuk meningkatkan kemampuan pemecahan masalah matematis pada siswa adalah dengan menggunakan model Problem Based Learning (PBL).

Model pembelajaran Problem Based Learning (PBL) adalah suatu pembelajaran yang mengacu pada keempat pilar pendidikan universal, yaitu belajar memahami, belajar melaksanakan atau melakukan, belajar menjadi diri sendiri, belajar bekerja sama atau hidup dalam kebersamaan Herman (Isrok'atun \& Rosmala, 2018:44). 


\section{Metode Penelitian}

Subjek dari penelitian ini adalah siswa kelas VII $^{2}$ SMP Negeri 12 Palembang yang berjumlah 28 siswa yang terdiri dari 13 orang laki-laki dan 15 orang perempuan dan dilaksanakan pada semester genap.

Metode penelitian ini adalah deskriptif dengan desain pembelajaran The One-Group Pretest-Postest Design. Dengan penerapan model pembelajaran Problem Based Learning (PBL). Untuk lebih jelasnya dapat dilihat pada gambar dibawah ini.

\section{$\mathrm{O}_{1} \times \mathrm{O}_{2}$}

Gambar 1.The One-Group PretestPostest Design

(Lestari, 2015 :123)

Keterangan:

X : Perlakuan yang diberikan model pembelajaran PBL

$\mathbf{O}_{1}$ : Pretest untuk mengukur kemampuan awal pemecahan masalah matematis

$\mathbf{O}_{2}$ : Posttest untuk mengukur kemampuan akhir pemecahan masalahmatematis

Sebelum perlakuan model pembelajaran Problem Based Learning (PBL), peneliti memberikan pretest (tes awal) kemudian diberikan perlakuan tiap pertemuan dan selanjutnya diberikan Postest ( tes Akhir).

\section{Hasil Dan Pembahasan}

Penelitian ini berjudul "Penerapan Model Pembelajaran Problem Based Learning (PBL) Untuk Meningkatkan Kemampuan Pemecahan Masalah Matematis Siswa di SMP Negeri 12 Palembang”. Penelitian ini dilaksanakan di SMP Negeri 12 Palembang pada semester genap mulai tanggal 18 Juli 2019 sampai dengan 26 Juli 2019. Pelaksanaan penelitian ini dilakukan dengan tiga tahap yaitu tahap persiapan, pelaksanaan, dan pelaporan.

Pada tahap persiapan, Peneliti mengurus surat penelitian di Fakultas Keguruan dan Ilmu Pendidikan Universitas PGRI Palembang. Setelah peneliti mendapat surat pengantar untuk melaksanakan penelitian dari Universitas PGRI Palembang, selanjutnya peneliti mengurus surat izin penelitian tersebut ke Dinas Pendidikan Kota Palembang. Pada tanggal 17 juli 2019 peneliti mendapatkan surat rekomendasi izin penelitian di SMP Negeri 12 Palembang dari Dinas Pendidikan Kota Palembang, dan pada hari itu juga surat izin tersebut diserahkan kepada Kepala SMP Negeri 12 Palembang, peneliti berkesempatan bertemu langsung dengan Kepala SMP Negeri 12 Palembang, yakni Bapak Mgs Ahmad Fauzi, S.Pd.,M.M kemudian peneliti membicarakan rencana penelitian yang akan dilaksanakan pada sekolah 
tersebut dan dengan segala pertimbangan beliau mengizinkan peneliti untuk melakukan penelitian selama kurang lebih dua minggu. Sebelum mengadakan penelitian, peneliti terlebih dahulu melakukan observasi disekolah tersebut yang dilakukan pada hari Rabu, tanggal 17 Juli 2019, dari observasi tersebut peneliti mendapat informasi bahwa subjek dalam penelitian ini adalah kelas VII SMP Negeri 12 Palembang pada tahun ajaran 2018/2019 terdiri dari 9 kelas yang berjumlah 252 siswa dan yang menjadi sampel dalam penelitian ini adalah kelas VII $^{2}$ yang berjumlah 28 siswa, (Informasi data didapat dari TU SMP Negeri 12 Palembang).

Tahap pelaksanaan, pada tahap pelaksanaan peneliti melaksanakan pembelajaran berdasarkan RPP yang telah dibuat sebelumnya. Pelaksanaan pembelajaran pada kelas VII $^{2}$ di SMP Negeri 12 Palembang dengan menggunakan model pembelajaran Problem Based Learning (PBL). Pelaksanaan penelitian dilakukan sebanyak 5 kali pertemuan, dengan 1 kali tes awal (pretest), 3 kali kegiatan pembelajaran dan 1 kali tes akhir (posttest), setiap pertemuan berlangsung selama 2 x 40 menit (2 jam pelajaran) dengan soal yang diberikan adalah soal essay dan materi yang akan dipelajari adalah Bentuk Aljabar.
Tahap pelaporan, data kemampuan pemecahan masalah matematis siswa diperoleh dari pemberian tes awal sebelum perlakuan (pretest) dan tes akhir sesudah perlakuan (posttest) diterapkannya model pembelajaran Problem Based Learning (PBL). Tes ini diberikan untuk mengetahui kemampuan pemecahan masalah matematis siswa sebelum dan setelah diterapkannya model pembelajaran Problem Based Learning (PBL) dalam pembelajaran matematika pada materi bentuk aljabar di SMP Negeri 12 Palembang.

Hasil perhitungan secara umum mengambarkan bahwa nilai rata- rata skor hasil tes awal (Pretest) kemampuan pemecahan masalah matematis siswa sebelum diberi perlakuan model pembelajaran Problem Based Learning (PBL) adalah 55,65 sedangkan nilai ratarata skor hasil tes akhir (Posttest) kemampuan pemecahan masalah matematis siswa setelah diberi perlakuan model pembelajaran Problem Based Learning (PBL) adalah 83,26 dengan skor maksimal yaitu 48. Kemudian dari skor yang didapat dianalisis menggunakan gain ternormalisasi (normalized gain).

Hasil data tes kemampuan pemecahan masalah matematis siswa untuk tes awal (pretest) dan tes akhir (posttest) menggunakan Uji $\mathrm{N}$ gain. Uji $\mathrm{N}$ gain digunakan untuk mengetahui 
peningkatan kemampuan pemecahan masalah matematis siswa setelah diterapkannya model pembelajaran Problem Based Learning (PBL) di SMP Negeri 12 Palembang.

Data mengenai kemampuan pemecahan masalah matematis siswa diperoleh dari hasil tes dengan menggunakan tipe soal pemecahan masalah matematika. Tes dilaksanakan pada pertemuan awal dan pertemuan akhir. Pada pelaksanaan tes dilakukan secara individu. Penskoran yang dilakukan adalah sesuai dengan rubrik penskoran yang telah dibuat. Tiap soal mempunyai empat indikator kemampuan pemecahan masalah matematis yang skornya telah ditetapkan.

Hasil analisis secara umum mengambarkan bahwa: (1) Nilai rata- rata hasil tes awal (Pretest) kemampuan pemecahan masalah matematis siswa sebelum diberi perlakuan model pembelajaran Problem Based Learning (PBL) adalah 55,65 dengan standar deviasi 5,734; (2) Nilai rata- rata hasil tes akhir (Posttest) kemampuan pemecahan masalah matematis siswa setelah diberi perlakuan model pembelajaran Problem Based Learning (PBL) adalah 83,26 dengan standar deviasi 5,692.
Data deskriptif pemecahan masalah matematis siswa disajikan pada tabel berikut.

Tabel 1. Hasil Tes Kemampuan Pemecahan Masalah Matematis Siswa

\begin{tabular}{|l|c|c|c|c|}
\hline & Mean & N & $\begin{array}{c}\text { Std. } \\
\text { Deviation }\end{array}$ & $\begin{array}{c}\text { Std. Error } \\
\text { Mean }\end{array}$ \\
\hline Pretest & 55,65 & 28 & 5,734 & 0,4424 \\
\cline { 2 - 5 } Posttest & 83,26 & 28 & 5,692 & 0,4004 \\
\hline
\end{tabular}

Dari data hasil penelitian menunjukan bahwa nilai rata- rata hasil tes awal (Pretest) kemampuan pemecahan masalah matematis siswa sebelum diberi perlakuan lebih kecil dibandingkan dengan nilai rata- rata hasil tes akhir (Postest) kemampuan pemecahan masalah matematis siswa setelah diberi perlakuan. Adapun hasil analisis peningkatan kemampuan pemecahan masalah matematis siswa per indikator dapat dilihat pada tabel dibawah ini :

\section{Tabel 2. Hasil Rata-Rata Tes Akhir} Siswa Perindikator

\begin{tabular}{|c|l|c|c|}
\hline No. & \multicolumn{1}{|c|}{$\begin{array}{c}\text { Indikator } \\
\text { Kemampuan } \\
\text { Pemecahanmasalah }\end{array}$} & $\begin{array}{c}\text { Skor } \\
\text { Pretest }\end{array}$ & $\begin{array}{c}\text { Skor } \\
\text { Posttest }\end{array}$ \\
\hline 1 & Memahami masalah & 63 & 91 \\
\hline 2 & $\begin{array}{l}\text { Membuat model } \\
\text { matematika }\end{array}$ & 85 & 95 \\
\hline 3 & $\begin{array}{l}\text { Memilih strategi } \\
\text { pemecahan }\end{array}$ & 67 & 88 \\
\hline 4 & $\begin{array}{l}\text { Memeriksa kembali } \\
\text { jawaban yang } \\
\text { diperoleh }\end{array}$ & 8 & 60 \\
\hline
\end{tabular}


Dari tabel diatas dapat dilihat bahwa peningkatan kemampuan pemecahan masalah matematis siswa (IKPM) sebelum dan setelah diterapkannya model pembelajaran Problem Based Learning (PBL) per indikator mengalami peningkatan.

Tabel 3. Hasil Analisis N-Gain Tes Awal (Pretest) Dan Tes Akhir (Postest)

\begin{tabular}{llll}
\hline Rata- & Rata- & Indek & katego \\
Rata & Rata & s & ri \\
Pretest & Posttest & Gain & \\
\hline $\mathbf{5 5 , 6 5}$ & $\mathbf{8 3 , 2 6}$ & $\mathbf{0 , 6 2}$ & Sedang \\
\hline
\end{tabular}

Dari tabel di atas dapat di lihat nilai rata-rata tes awal (pretest) siswa adalah 55,65 sedangkan nilai rata-rata tes akhir (posttest) siswa adalah 83,26 sehingga diperoleh indeks gain sebesar 0,62. Setelah diinterpretasikan ke dalam klasifikasi Hake maka indeks gain 0,62 termasuk ke dalam katagori sedang. Jadi dapat disimpulkan bahwa peningkatan kemampuan pemecahan masalah matematis siswa setelah diterapkan model pembelajaran Problem Based Learning (PBL) di SMP Negeri 12 Palembang di katagorikan Sedang.

Berdasarkan hasil penelitian dan pembahasan diatas bahwa ada peningkatan kemampuan pemecahan masalah matematis siswa setelah diterapkan model pembelajaran Problem Based Learning (PBL) di SMP Negeri 12 Palembang. Hal ini sesuai yang di ungkapkan Duch (Shoimin, 2014 : 130) Problem Based Learning (PBL) adalah model pembelajaran yang bercirikan adanya permasalahan nyata sebagai konteks untuk para peserta didik belajar berpikir kritis dan keterampilan memecahkan masalah serta memperoleh pengetahuan. Sehingga pada penerapan model pembelajaran Problem Based Learning (PBL) dapat melatih siswa untuk lebih aktif dalam menyelesaikan suatu masalah dan membuat siswa mampu berusaha memecahkan permasalahan dalam kehidupan sehari-hari. Berdasarkan penelitian relevan yang dilakukan Nendri (2016) yang menyatakan bahwa model pembelajaran Problem Based Learning (PBL) lebih efektif dalam meningkatkan kemampuan pemecahan masalah matematis peserta didik. Begitu juga dengan penelitian yang dilakukan oleh ayu , dkk (2016) yang menyimpulkan bahwa kemampuan pemecahan masalah matematika siswa yang belajar menggunakan model Problem Based Learning (PBL) berada dalam kualifikasi baik dan model pembelajaran Problem Based Learning (PBL) memberi pengaruh pada kemampuan pemecahan masalah matematika. Sejalan yang disimpulkan oleh Elli Kusumawati (2015 : 222) yang 
menyatakan model pembelajaran memberikan pengaruh terhadap kemampuan pemecahan masalah matematis siswa, yakni meningkatkan kemampuan pemecahan masalah matematis siswa. Hal ini juga sesuai dengan pendapat ibrahim (Trianto, 2011 :96) bahwa pengajaran yang berdasarkan masalah untuk membantu siswa mengembangkan kemampuan berpikir, pemecahan masalah, dan keterampilan intelektual. Selain itu, sesuai dengan pendapat Trianto (2011 : 94) yang menjelaskan salah satu tujuan dari model pembelajaran Problem Based Learning (PBL) adalah membantu siswa mengembangkan keterampilan pemecahan masalah. Serta Bruner juga berpendapat bahwa berusaha sendiri untuk mencari pemecahan masalah serta pengetahuan yang menyertainya, menghasilkan pengetahuan yang benar-benar bermakna. suatu konsekuensi logis, karena dengan berusaha untuk mencari pemecahan masalah secara mandiri akan memberikan suatu pengalaman konkret, dengan pengalaman tersebut dapat digunakan pula memecahkan masalah-masalah serupa, karena pengalaman itu memberikan makna tersendiri bagi peserta didik.

Penerapan Model Pembelajaran Problem Based Learning (PBL) dapat menjadi salah satu alternatif dalam pembelajaran matematika yang yang 
Fauzi, S.Pd.,M.M., selaku kepala sekolah

SMP N 12 Palembang dan Ibu Maryati,

S.Pd selaku guru mata pelajaran Matematika yang telah memberikan kemudahan dalam pengumpulan data, serta pihak lain yang telah memberikan bantuannya sehingga artikel ini dapat penulis selesaikan.

\section{Pustaka}

Lestari, Eka Karunia, dan Mokhammad Ridwan Yudhanegara . 2015. Penelitian Pendidikan Matematika Jakarta : Refika Aditama.

Isrok'atun, dan Rosmala 2018. Modelmodel pembelajaran matematika. Jakarta : PT. Bumi Aksara.

Trianto. 2011. Mendesain model pembelajaran inovatif Progresif. Jakarta : Kencana.

Ayu, dkk. 2016. Pengaruh Model Pembelajaran Problem Based Learning (PBL) Terhadap Kemampuan Pemecahan Masalah Matematika pada siswa kelas VII SMPN 3 Rambah Samo. Jurnal Ilmiah Mahasiswa Matematika Vol. 2. No. 2.

Kesumawati, Elli, dan Muhammad S.K. 2015. Impelementasi Model Pembelajaran Problem Based Instruction Terhadap Kemampuan Pemecahan Masalah Matematis Siswa SMA. Junal Pendidikan Matematika dalam: EDU-MAT, Vol.3(2),213-223

Nendri, 2016. Pengaruh Model Problem Based Learning (PBL) Terhadap Kemampuan Pemecahan Masalah Matematis di SMA Negeri 4 Palembang. Skripsi SI (belum diterbitkan). Palembang: FKIP Universitas PGRI Palembang.

Wena, Made. 2011. Strategi Pembelajaran Inovatif Kontemporer
Suatu Tinjauan Konseptual Operasional. Jakarta: Bumi Aksara.

Shoimin, Aris. 2014. 68 Model Pembelajaran Inovatif dalam Kurikulum 2013. Yogyakarta: ArRuzz Media. 